\title{
Assessing Banks Internal and Macroeconomic Factors as Determinants of Non- Performing Loans: Evidence from Nepalese Commercial Banks
}

\author{
Bishnu Prasad Bhattarai ${ }^{1}$
}

\author{
${ }^{1}$ Dr. Bhattarai, Academic Director/ Business Unit Head, Excel Business College \& Faculty Member, Patan \\ Mutiple Campus, Faculty of Management, Patan Dhoka, Lalitpure,Nepal
}

Correspondence: Dr.Bhattarai, Academic Director/ Business Unit Head, Excel Business College \& Faculty Member, Patan Mutiple Campus, Faculty of Management, Patan Dhoka, Lalitpure, Nepal.Tel: +9779851103366, Email: abpbhattarai@gmail.com

To cite this article: Bhattarai, B. (2018). Assessing Banks Internal and Macroeconomic Factors as Determinants of Non- Performing Loans: Evidence from Nepalese Commercial Banks. International Journal of Accounting \& Finance Review, 3(1), 13-32. Retrieved from http://www.cribfb.com/journal/index.php/ijafr/article/view/28

Received: September 23, $2018 \quad$ Accepted: September 27, $2018 \quad$ Online Published: September 30, 2018

\begin{abstract}
This study has attempted to ascertain the factors affecting to non-performing loans in Nepalese commercial banks using a sample of ten commercial banks for the period of 2013-2017 with 50 observations, a balanced set of panel data. The descriptive and causal comparative research designs have been adopted for the study. The dependent variable was non-performing loans, while independent variables included both bank specific factors; bank size, return on assets, total loan and advance to total deposit ratio, capital adequacy ratio and macro-economic factors; real gross domestic product growth rate and inflation. The existence of high levels of NPLs would hinder the benefits to the county through inefficient financial intermediation. Hence, there is a national level responsibility towards banks, to manage the NPL ratio at an acceptable level. Consequently, it is important to identify "what causes NPLs and significance of these factors on NPLs". Therefore, this study would help to get an insight on the bank specific and macro-economic factors, which affect NPLs in commercial banks and in which magnitude bank specific or macroeconomic factors contribute to NPLs. The estimated ordinary least square (OLS) regression model reveals that the bank specific: ROA, LTD and CAR and macroeconomic factors GDP have significant impact on nonperforming loan in Nepalese commercial banks.
\end{abstract}

Keywords:Nonperforming loan, total assets, return on assets, capital adequacy ratio, loan to deposit ratio, annual gross domestic products and annual inflation rate. 


\section{Introduction}

Non-Performing Loan (NPL) has been crucial factor these days in terms of Banking sector sustainability and profitability. The economic development of a nation and stability of banking system are invariably interrelated. International experience shows that if NPA is not managed properly, it will lead to banking failures and nationwide financial fragility. Regular monitoring of loan quality is thus essential to ensure a sound financial system and possibly provides an early alarm to regulatory authorities of banking system (Prasanna et al., 2014). In every economy financial institutions has got a major role to play. Every developed and sound financial institution has got the ability to absorb economic jolts and keep the economic system on track (Aburime, 2009). In that respect every country's central bank has got a major role to play in form of keeping the financial system on track, so that the consistent economic sustainability can be achieved. However, a few difficulties are faced by the central banks of different countries. The responsibility of the central bank is to regulate financial system and institutions, while financial institutions which report to central bank have the responsibility of implementing the regulations and policies set by the central bank. Commercial banks receive deposits from the customer, and then lends, it in shape of credit.

Among various indicators of financial stability bank's nonperforming loans assume critical importance since it contemplates on the asset quality, credit risk and efficiency in the allocation recourses to the productive sector. A non performing loan is any loan in which interest and principle payments are more than 90 days overdue. (IMF; 2005).

In this connection, the main research question in this study as follow: Do bank specific and macroeconomic variables have an impact on the nonperforming loan of Nepalese commercial banks?

Increase non performing loans as the result of ultimate failure of credit policy. It is also observed that the financial crisis is also affected of high NPLs rate in the banking sector. The reason behind the bad debts is the low repaying capacity of the borrower. Ultimately banks have failure.

Financial institutions failing to operate well and unable to properly lend depositors are declared as problematic institutions by Nepal Rastra Bank. This post includes the list of such problematic institutions. Nepal Rastra Bank regularly monitors, supervisies and regulates licensed financial institutions. Inspite of such tools many institutions are declared problematic and are under direct control, monitoring as well corrective actions. Till date NRB have declared 16 financial institutions as problematic among which 4 institutions are liquidated (gone liquidation). The failure Banks and financial instution are: Himalayan Finance Limited (Bagdarbar/Sundhara, 
Kathmandu), Nepal Development Bank (Kamaladi, Kathmandu), Samjhana Finance (Banepa, Kavrepalanchok) and United Bikash Bank (Birgunj, Parsa) (Bajgain, Jun2, 2016).

In Nepal, NRB has also given direction for lending to Lending to Deprived Sector. At present the lending in deprived sector must be $5 \%$ of total outstanding loans As regards lending to priority sector, Banks should lend at least $25 \%$ in sectors like agriculture (10\%), energy (5\%), tourism (5\%) and rest of the amount in others sector (export, small and medium enterprises, pharmaceuticals, cement and garment).

The total volume of non- performing loans of the commercial banks decreased by Rs.3.74 billion in the fiscal year 2015/16 and reached Rs. 23.77 billion, which is 1.74 percent of total outstanding loan and advances as at Mid July 2016.

There has been a marginal decline in the non-performing loan (NPL) of the BFIs. Such loan came down to 1.7 percent in mid-April 2017 from 1.8 percent in mid-July 2016. Credit to core capital cum deposit (CCD) ratio of commercial banks remained 70.96 percent in mid- June 2017. This is after allowing BFIs to deduct up to 50 percent of productive sector loan from CCD ratio computation. However, such ratio without such concession to the banks stands 77.46 percent (Monetary Policy, 2017/18, NRB).

In this context, the purpose of this study is to analyze the impact of bank specific and macroeconomic variables on the nonperforming loan of commercial banks of Nepal.

Specially, it examines the non performing loan of commercial banks through the internal and environmental variables of size, profitability, capital adequacy ratio, loan to deposit ratio and annual growth of gross domestic product, and inflation. The data were collected from Economic Survey and annual reports of selected banks including their websites.

The finding of this study has been reported that the average NPL ratio is in the period from 2013 to 2017: 1.34 percent with a dispersion of 1.10 percent. The bank with lowest NPL rate is Nepal SBI bank (2016/2017): 0.10 percent and bank with highest NPL ratio is Sunrise bank (2013/2014): 5.20 percent. The study concluded that bank specific: ROA, LTD and CAR and macroeconomic factors GDP have significant impact on nonperforming loan.

The remainder of this study is organized as follows. Section two has explains about reviews of literature, Section three the methodology and section four analysis of results and section five conclusion.

\section{Literature Review}

Sinkey and Greewalt (1991) have found that the developed country such as USA had rising level of NPL that 
cause banks failure. Alton and Hazen (2001) have analyzed non-performing loans as advances that are not being repaid for a specified period of time. Hennie (2003) has termed NPLs that are not generating profits. Godlewski (2004) has investigated that a relationship exists between Return on asset (ROA) and NPLs. The lower the return on asset the higher will be the NPLs and vice versa.

Ahikary et al. (2007) have explored that the amount of non-performing loan is one of the indicators of performance of the economy. Less the NPL, better the financial health of the economy. If the non-performing loan is more, there will be poor financial health and crisis may result in the economy. In the past before 2001, Nepal bank limited and RBBL nearly collapsed due to high non-performing loan of over fifty percent of their total assets. Because of which NRB with the support of IMF and World Bank adopted a reform program.

Boudriga, Taktak and Jellouli (2010) have analysed the impact of bank-specific, business and institutional environmental factors on non-performing loans for a sample of forty-six banks from twelve countries in the Middle East and North Africa (MENA) region for the period 2002 to 2006. The results revealed that among the bank-specific factors, foreign participation coming from developed countries, credit growth and return on assets have significant negative influence on non-performing loans, while capital adequacy and loan loss provisions have a positive and significant impact. The results also highlighted the importance of the institutional environment in enhancing credit quality. Specifically, better enforcement of rule of law, sound regulatory quality, better control of corruption, and free. The voice and accountability were significant in reducing non-performing loans. With regards to the business environment, quality of information published by private and public credit bureaus, and legal rights were significant in reducing non-performing loans in the MENA countries.

Guy and Lowe (2011) have indicated that GDP growth, inflation and lending rate have significant negative impact on non-performing loans, while loan growth, loan to deposit ratio and ROA were shown to be insignificant variables.

Sapkota (2011) has found that Nepal is also facing banking crisis and some of the bank and financial institutions have already failed during last few years and are in the process of liquidation. The Study showed that the failure of banks in Nepal was also the result of the high non-performing assets, lending without differentiating markets, products and borrowers' credit worthiness and excessive loan exposure to real estate.

Roy (2014) has emphasized that level of banks"e credit plays an important role in economic developments. Indian banking sector has played a seminal role in supporting economic growth in India. Recently, Indian banks are experiencing consistent increase in non-performing assets (NPA). In this perspective, this paper investigates the 
trends in NPA in Indian banks and its determinants. The panel regressions, fixed effect allows evaluating the impact of selected macroeconomic variables on the NPA. The Panel regression result indicates that the GDP growth, change in exchange rate and global volatility have major effects on the NPA level of Indian banking sector.

Jameel (2014) has examined the impact of bank's significant determinants on nonperforming loans in the Pakistani banking sector. To accomplish this purpose 11 years (2000-2010) time series data have been collected which has explained the relationship between non performing loans and several bank's determinants. Quantitative data examined by using Econometric models with the help of Eview 6.0.The study occupy time series data multiple liner regression model. For this purpose, bank's specific indicators such as Gross domestic Product, Weighted average lending rate, loan's maturity time period, Credit deposit ratio, and Capital adequacy ratio are regressed against amount of nonperforming loans to total advances. The study found that GDP growth rate, maturity time period of loans, capital adequacy ratio and credit deposit ratio have negatively associated with NPLs in Pakistan banking sector. While weighted average lending rate has positive relation with NPLs in Pakistan.

Amuakwa-Mensah and Boakye-Adjei (2015) have analyzed that the detrimental effect non-performing loans (NPLs) have on banks' income and the economy makes it necessary to examine the determinants of NPLs in the banking industry in Ghana. Using panel regression model, it was found that both bank-specific variables (i.e., previous year's NPL, bank size, net interest margin (NIM), and current year's loan growth) and macroeconomic variables (i.e., previous year's inflation, real gross domestic product (GDP) per capita growth and real effective exchange rate) significantly affect NPLs in the banking industry. Also the sub-sample estimations showed that both bank specific (i.e., previous year's NPLs and current year's loan growth) and macroeconomic factors (i.e., real effective exchange rate, real GDP per capita growth, and previous year's inflation rate) affect NPLs of large banks. However, whereas bank-specific variables (i.e., previous year's NPLs and current year's loan growth) are important in explaining NPLs, macroeconomic factors are not important in explaining NPLs for small banks.

Bhattarai (2015) have examined the non-performing loans (NPL) of financial institutions are considered as a significant issue in the context of Nepal for last few decades. The paper aims to identify the impact of macroeconomic variables (GDP, Inflation, and Real Effective Exchange Rate) and bank specific variables (size, change in loan, real lending rate of interest, and share of loan to total assets) on the non-performing loan of the commercial banks in Nepal. The study was conducted mainly with secondary sources. The data were collected for 
26 commercial banks covering the period of 2002-2012 with 227 observations. The study found that macroeconomic variables such as the real effective exchange rate have significantly negative impact on non-performing loan. The impact of GDP growth rate was found to be insignificant in this study. One year lagged inflation rate has significant positive impact on non-performing loan. The banks which charge relatively higher real interest rate have higher non-performing loan, which is consistent with the findings of previous studies. The ownership dummy has positive coefficient and significant at one percent level showing that if the bank is government owned the non-performing loan would be higher than that of the private owned banks. As well, more lending in the previous years and current year reduces the non-performing loan since the coefficient of change in loan in current and previous years have negative coefficient and significant at one percent level.

Ekanayake and Azeez (2015) have investigated the determinant factors of ex-post credit risk considering non-performing loans (NPLs) as proxy variable in Sri Lanka's commercial banking sector and is carried out with a sample of nine licensed commercial banks for the period from 1999 to 2012. The study finds that the level of NPLs can be attributed to both macroeconomic conditions and banks' specific factors. It reveals that, NPLs tends to increase with deteriorating bank's efficiency. There is also a positive correlation between loan to asset ratio and NPLs. Meanwhile, banks with high level of credit growth associated with a reduced level of non- performing loans. Larger banks incur lesser loan defaults compared to smaller banks. With regard to macro-economic variables, NPLs vary negatively with the growth rate of GDP and Inflation and positively with the prime lending rate.

Ozurumba (2016) has examined the impact of Non-performing Loans on the Performance of Selected Commercial Banks in Nigeria covering the period 2000 - 2013 with special emphasis on Access Bank, United Bank for Africa and Union Bank of Nigeria Plc. It specifically determined the effect of non-performing loans, provision for loan loss and loans and advances on the performance of banks measured by Return on Assets and Return on Equity. The study utilized secondary data obtained from annual report and accounts of the selected banks for the period under study. The data were analyzed using ordinary least square method and ratio analysis. The specific finding of the work is that return on asset and return on equity have inverse relationship with non-performing loans and loan loss provision respectively while they are positively related to loans and advances. The conclusion therefore is that the effects of non-performing loans on Commercial Banks' performance is negative and cannot be underestimated, and poses a fundamental danger to the very existence of the Banks as corporate business entities. 
Rajha (2016) has investigated the determinants of non-performing loans in the Jordanian banking sector during the period 2008-2012. The study used macroeconomic and bank specific factors to identify the determinants of NPLs of Jordanian banks. Using panel data regression, our results report that among bank specific factors, the lagged NPLs and the ratio of loans total assets were the most important factors that affect nonperforming loans positively. However, contrary to international evidence our results show that large banks are not necessarily more effective in screening loan customers when compared to their smaller counterparts. With respect to the macroeconomic factors, we found that economic growth and inflation rate have a negative and significant effect on non-performing loans. In addition, we found that global financial crisis lead to higher non-performing loans in Jordan.

Khan and Ahmad (2017) have explored that Non-Performing Loan (NPL) has been crucial factor these days in terms of Banking sector sustainability and profitability. This paper intends to assess factors that may influence the rising level of nonperforming loans in commercial banks of Pakistan. The study uses Size, Return on Assets, Earning per Share, Cash to Total Asset, and investment to Total Asset, Capital Adequacy Ratio and Breakup value per share as determinants of nonperforming loans as banks internal factors. Panel data from 2006-2016 were taken from published annual reports and State Bank of Pakistan. Descriptive Statistics, correlation analysis and random effect panel least square regression was used to analyze data through STATA application software. The analysis leads to the conclusion that reduced level of nonperforming loans leads to increased banks performance. It was also concluded that Return on Asset, Earning per share, Capital adequacy ratio and Breakup value per share has got a significant impact on nonperforming loans.

Wood and Skinner (2018) have analyzed that the commercial banking sector is the primary form of financial intermediation in Barbados. It is the largest conduit for the mobilisation of domestic savings, main source of external capital for firms and key player in the payment system. With the onset of the global financial crisis in 2008, the financial indicators of the commercial banking sector worsened with credit quality in particular being noteworthy. The non-performing loans to total loans ratio increased from a historic low of $2.9 \%$ in 2007 to $12.9 \%$ in 2012. Given the adverse effect of non-performing loans on the financial performance of commercial banks, there has been a proliferation of studies on the determinants of non-performing loans over the years. This paper examines the bank-specific and macroeconomic determinants of non-performing loans of commercial banks in Barbados over the period 1991-2015. The empirical results indicate that the bank-specific factors: return on equity, return on assets, capital adequacy ratio and loan to deposit ratio are significant determinants of 
non-performing loans, while the macroeconomic variables exerting significant influence are GDP growth, unemployment and interest rate. Based on the above findings, the work recommends that banks should maintain high credit standards while the Apex Bank and other regulatory agencies should maintain high surveillance on banks' credit operations.

\section{Conceptual Frame Work}

The main objective of this study is to examine the determinants o NPLs of commercial banks in Nepal. Based on the objective of the study, the following conceptual model is framed. As previously discussed in the related literature review parts, nonperforming loans are affected by both bank specific and macroeconomic factors. Bank specific factors are bank size (LnTA); return on assets (ROA); liquidity (LTD); capital adequacy ratio (CAR); whereas macroeconomic factors are real gross domestic growth rate (RGDP) and inflation rate (INF). Thus, the following conceptual model is framed to summarize the main focus and scope of this study in terms of variables included. The conceptual framework is developed from the prior theoretical and empirical grounds.

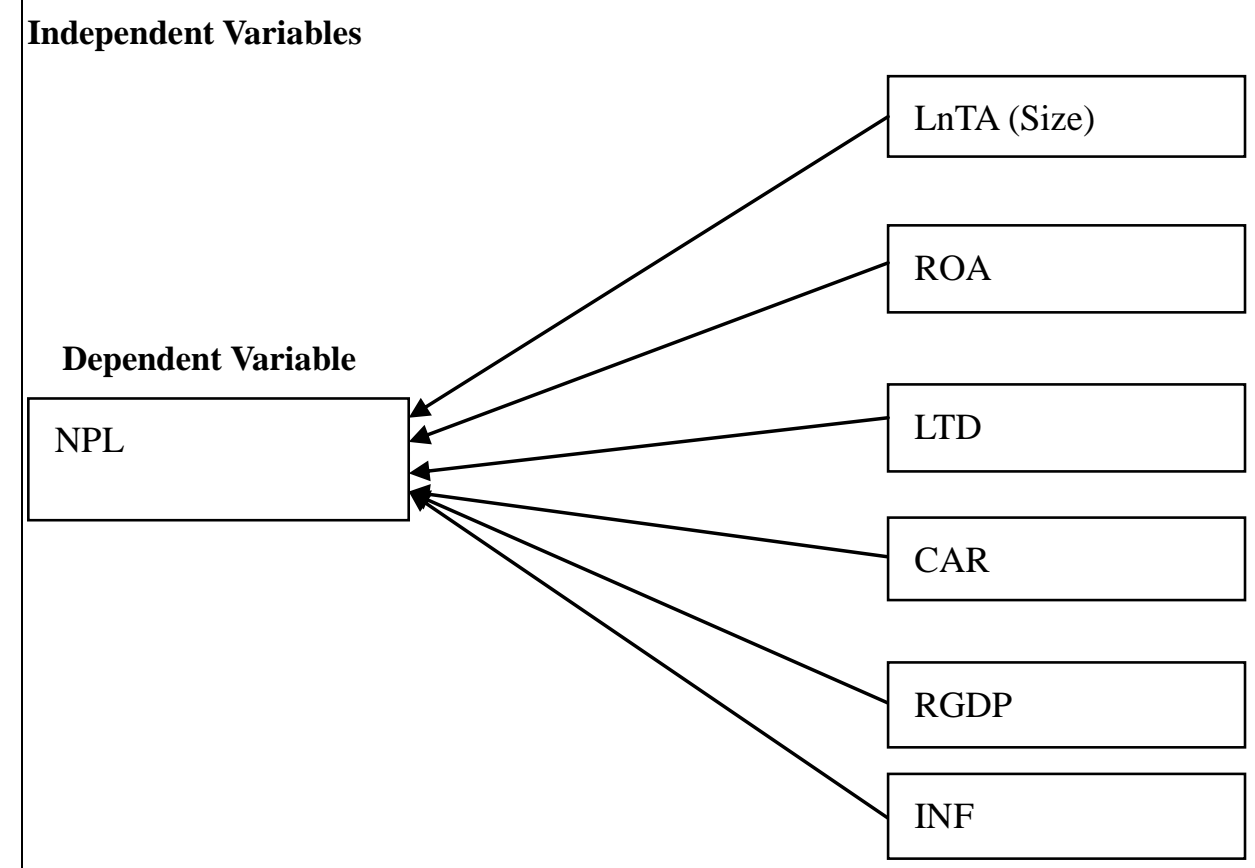

Figure 1: Conceptual Framework

Source: Conceptual Framework Developed by Researcher (2018)

The conceptual framework presented in the Figure 1 developed to test the effect of these independent variables on the nonperforming loan of sample commercial banks of Nepal. 


\section{Research Methodology}

A sample of 10 commercial banks has been taken out of 28 commercial banks. In this study, convenience sampling technique has been used to select the banks as sample. Convenience sampling involves choosing respondents or organization as sample at the convenience of the researcher. In view of speedy collection and cost effective, this study has adopted convenience sampling technique in order to select the banks as sample.

The reason behind choosing of the latest five year from 2012 to 2017 period is to include a fresh data in the analysis. This study has adopted descriptive and causal comparative research design. The selected commercial banks of the study are Nabil Bank, Standard Chartered Bank, Nepal Investment Bank, Himalayan Bank, Everest Bank, Neap SBI Bank, Nepal Bangladesh Bank, Machhapuchhere Bank, Siddhartha Bank, and Sunrise Bank.

\subsection{The Model}

The study uses the following Ordinary Least Square (OLS) regression model to assessing banks internal and macroeconomic factors as determinants of nonperforming loans: Evidence from Nepalese commercial banks.

$$
\mathrm{NPL}_{i t}=\beta_{0}+\beta_{1} \mathrm{LnTA}_{\mathrm{it}}+\beta_{2} \mathrm{ROA}_{\mathrm{it}}+\beta_{3} \mathrm{LTD}_{\mathrm{it}}+\beta_{4} \mathrm{CAR}_{\mathrm{it}}+\beta_{5} \mathrm{RGDP}_{\mathrm{it}}+\beta_{6} \mathrm{INF}_{\mathrm{it}}+\varepsilon_{\mathrm{it}}
$$

Where:

NPL ${ }_{\text {it }}$ Ratio of non-performing loans to total loans of $\mathrm{i}^{\text {th }}$ bank for the time period $\mathrm{t}$

SIZE it Logarithm of Total Assets of $\mathrm{i}^{\text {th }}$ bank for the time period $\mathrm{t}$

$\mathrm{ROA}_{\text {it }} \quad$ Ratio of net income to total assets of $\mathrm{i}^{\text {th }}$ bank for the time period $\mathrm{t}$

LTD $_{\text {it }} \quad$ Ratio of Total Loan and advance to total deposit of $i^{\text {th }}$ bank for the time period $\mathrm{t}$

CAR it Capital Adequacy Ratio approximated by total funds to total assets of $\mathrm{i}^{\text {th }}$ bank for the time period $\mathrm{t}$

RGDP $\mathrm{t} \quad$ Real gross domestic product growth rate for the time period $\mathrm{t}$

INF $\mathrm{t} \quad$ Inflation Rate for the time period $\mathrm{t}$

$\beta_{0} \quad$ The intercept (constant)

$\beta_{1}, \beta_{2}, \beta_{3}, \beta_{4}, \beta_{5} \beta_{6}$, The slope which represents the degree with which bank loan loss 
provisions changes as the independent variable changes by one unit variable.

$\varepsilon_{\text {it }}$ error component

\subsection{Variables and Hypothesis}

\subsubsection{Dependent Variables}

\subsubsection{Nonperforming Loan}

Nonperforming loans (NPLs) are loans that are outstanding both in its principal and interest for a long period of time contrary to the terms and conditions under the loan contract. Any loan facility that is not up to date in terms of payment of principal and interest contrary to the terms of the loan agreement is NPLs. Thus, the amount of nonperforming loan represents the quality of bank assets (Tseganesh, 2012). Rising trend of NPL ratio impairs asset quality of banks which eventually hindering solvency position of a bank. The main function of banks is credit creation through mobilization of deposits. Economic growth cannot prosper without strong financial sector. If financial soundness is week it can trim down credit flow in country which ultimately hampers the efficiency and productivity of growing industries. Increase non performing loans as the result of ultimate failure of credit policy. It is also observed that the financial crisis is also affected of high NPLs rate in the banking sector. The reason behind the bad debts is the low repaying capacity of the borrower (Jameel, 2014).

\subsubsection{Independent Variables \\ 4.2.2.1 Internal Factors \\ - Bank Size}

The size is positive but insignificant. This evidence which is inconsistent with previous studies (Rajan and Dhal, 2003; Salas and Saurina, 2006 and $\mathrm{Hu}$ et al, 2006) can be interpreted to mean that large banks are not necessarily more effective in screening loan customers when compared to their smaller counterparts. However, literature provides conflicting theoretical opinions. A negative relationship may mean that a larger banking industry is able to adopt better risk management strategies then a smaller one. On the contrary, in larger sized industries, banks may often resort to excessive risk taking since it is difficult to impose market discipline by regulators and thus they also expect government protection in the case of failures. This is in line with the notion of "too big to fail" therefore suggesting a positive relationship between the two variables (Ghosh, 2015). The study expects a positive effect of size on NPLs.

H1: Bank Size has a positive relationship with Nonperforming loans (NPLs). 
The return on assets indicates the ability of bank management to generate profits by utilising the available assets of the bank. Theoretically, the impact of ROA on non-performing loans is ambiguous. A positive impact can be rationalized through the behaviour of bank management. In order to increase short-term earnings, bank management may portray a wrong picture to investors relating to the future profitability and positive return prospects. As a consequence investors access funds from banks and invest in less profitable projects. This results in current good performance and profitability of the banks. However, because of the incorrect forecasting, returns on investment are not in accordance with investors' expectations, resulting in inability of investors to repay their loans and, hence, increases in non-performing loans in the future (Ahmad and Bashir, 2013a). Conversely, the negative influence of ROA on non-performing loans can rest on the view that banks with strong profitability have less incentive to generate income and are less inclined to engage in the granting of risky loans. ROA represents efficiency in asset utilization and shows how much net income is generated out of assets. It indicates the ability of bank management to generate profits by utilizing the available assets of the bank. Thus, if the ratio of ROA is high, it indicates that it is better performance in order to generate profit. Strong bank profitability measured in terms of ROA might result from high lending rate, fees and commission that lead bank growth in size and profitability. Thus, ROA gives an idea as to how efficient management is at using its assets to generate earnings. Different researchers found different results regarding the relationship between ROA and NPLs. Ahmed and Bashir (2013) and Makri et al.(2014),) were examined positive significant relationships between ROA and NPLs. However, Boudriga et a., (2009) and Selma and Jouini (2013) found negative association between NPLs and ROA by supporting the arguments that states deterioration of profitability ratio measured in terms of ROA leads to riskier activities of banks and then raise the level of NPLs. They justified that since ROA represents efficiency in asset utilization, poor utilization of assets leads higher NPLs for the banks. Thus, this ratio is expected to have negative relationships with NPLs in this study

\section{H2: Return on asset (ROA) has negative relation with Nonperforming loans (NPLs) of banks.}

\section{- Loan to Deposit (LTD) Ratio}

The loan to deposit ratio is a commonly used statistic for assessing a bank's liquidity and it reflects the utilization of funds policy of the bank. An increase in this ratio is indicative of the bank deploying more funds to loans. Such a situation reflects a less liquid position for the bank. The literature suggests that the LTD ratio has a positive effect on the level of non-performing loans. The justification for such a result is that the growth of customer deposits 
impacts positively on a bank's lending activity. Inefficiencies in the credit administration process in such circumstances can result in a higher level of non-performing loans.

\section{H3: Loan to deposit (LTD) ratio has positive relation with Nonperforming loans (NPLs) of banks. \\ - Capital Adequacy Ratio (CAR)}

The capital adequacy ratio measures a bank's solvency and ability to absorb risk. It is used to protect depositors, and promote stability and efficiency in the financial system. Theoretically, the impact of CAR on non-performing loans is uncertain. On the one hand, banks with high levels of CAR may pursue opportunities more aggressively, which means increased risk taking leading to riskier credit portfolios (Demirguc-Kunt and Huizinga, 1999). The ratio of capital adequacy is also measure of bank`s financial strength since it shows the ability to withstand/tolerate with operational and abnormal losses. It also represents the ability to undertake additional business (Habtamu, 2012). As noted by Makri et al.(2014), CAR determines risk behavior of banks. It is a measure of banks solvency and ability to absorb risk. Thus, this ratio is used to protect depositors and promote stability and efficiency of financial systems. According to Makri et al.(2014), there is negative relationship with NPLs indicating a risky loan portfolio is marked by a high NPL (equivalent to high credit risk). However, Djiogap and Ngomsi (2012) found positive association between NPLs and capital adequacy ratio. It is measured by total Equity to total asset ratio. However, it is expected to have negative association with NPLs in this study.

H4.Capital adequacy ratio (CAR) has negative relation with Nonperforming loans (NPLs) of banks.

\subsection{Macroeconomics Variables}

\subsubsection{Gross Domestic Product Growth Rate (GDP)}

Salas and Saurina (2002) have found a significant negative effect of GDP growth on NPLs. Economic growth usually increases the income which ultimately enhances the loan payment capacity of the borrower which in turn contributes to lower bad loan and vice versa (Khemraj and Pasha, 2009). Accordingly we expect a negative effect of economic growth on NPLs.

H5: Gross domestic product growth rate (GDP) has negative relation with Nonperforming loans (NPLs) of banks.

\subsubsection{Inflation Rate (INF)}

Khemraj and Pasha (2009) and Fofack (2005) have found a positive relationship between the inflation NPLs. While Nkusu, (2011) argued that inflation can affects the borrowers loan payment capacity positively or negatively, higher inflation can enhance the loan payment capacity of borrower by reducing the real value of 
outstanding debt; moreover increased inflation can also weaken the loan payment capacity of the borrowers by reducing the real income when salaries are sticky. So according to literature relationship between inflation and nonperforming loans can be positive or negative depending on the economy of operations (Farhan et al. 2012). The present study has positive relation with Nonperforming loans (NPLs) of banks.

\section{H6: Inflation rate (INF) has positive relation with Nonperforming loans (NPLs) of banks.}

The selected study variables, basis of measurement and priori expected sign have been depicted in Table 1 .

Table 1 Summary of Variables

\begin{tabular}{|c|c|c|c|}
\hline Notation & Measurement & $\begin{array}{l}\text { Expected } \\
\text { Sign }\end{array}$ & Some Empirical Evidence \\
\hline NPL & $\begin{array}{l}\text { Nonperforming Loans to } \\
\text { Total Assets }\end{array}$ & + & \\
\hline TA & $\begin{array}{l}\text { Natural logarithm of } \\
\text { total Assets }\end{array}$ & - & Rajan and Dhal, 2003; Salas and Saurina, 2006 and Hu et al, 2006 \\
\hline ROA & $\begin{array}{l}\text { Net Profit after Tax to } \\
\text { total assets }\end{array}$ & + & Swamy(2012), Selma and Jouini(2013), Bougriga et al. (2009) \\
\hline LTD & $\begin{array}{l}\text { Total Loan and Advance to } \\
\text { Total Deposit }\end{array}$ & - & Swamy (2012) \\
\hline CAR & Capital Adequacy Ratio & - & Shingjerji(2013),Hyun\&Zhang(2013),Makri et al.(2014), Klein(2013) \\
\hline GDP & $\begin{array}{l}\text { Gross Domestic Product } \\
\text { Annual Growth Rate }\end{array}$ & + & $\begin{array}{l}\text { Salas and Saurina (2002); Louzis et al. (2012); Messai and Jouini (2013); } \\
\text { Nkusu (2011); Makri et al. (2014); Klein (2013); Beck et al. (2013); } \\
\text { and Tanasković and Jandrić (2015). }\end{array}$ \\
\hline INF & Annual Inflation Rate & + & Khemraj and Pasha (2009) and Fofack (2005) \\
\hline
\end{tabular}

5. Results and Discussion

\subsection{Descriptive Statistics}

The descriptive statistics of input data (reported in Table 2) shows that the average NPL ratio is in the period from 2013 to 2017: 1.34 percent with a dispersion of 1.10 percent. The bank with lowest NPL rate is Nepal SBI bank (2016/2017): 0.10 percent and bank with highest NPL ratio is Sunrise bank (2013/2014): 5.20 percent.

The value of Bank size is Rs. 72116.38 (millions). The maximum value of size is Rs 150818.03(millions) of NIBL and bank with lower size is Rs. 21801.80 (million) NBBL(2012/13). ROA minimum value is 0.83 percent while maximum is 3.57 percent and standard deviation is 0.58403 that is low. The mean for ROA is 2.014 percent. 
Table 2 Descriptive Statistics of Sample Banks

\begin{tabular}{lrrrrr}
\hline Variables & N & \multicolumn{1}{c}{ Minimum } & \multicolumn{1}{c}{ Maximum } & \multicolumn{1}{c}{ Mean } & \multicolumn{1}{c}{ S.D } \\
\hline NPL & 50 & .10 & 5.20 & 1.3368 & 1.10199 \\
\hline TA & 50 & 21801.80 & 150818.03 & 72116.3790 & 31284.11130 \\
\hline ROA & 50 & .83 & 3.57 & 2.0138 & .58403 \\
\hline LTD & 50 & 48.92 & 87.28 & 73.1696 & 9.33116 \\
\hline CAR & 50 & 10.84 & 21.08 & 12.5188 & 1.85699 \\
\hline GDP & 50 & .01 & 7.40 & 3.9720 & 2.53760 \\
\hline INF & 50 & 4.50 & 9.90 & 8.1200 & 2.08238 \\
\hline
\end{tabular}

Source: Annual Reports of Sample Banks and Results are drawn from SPSS - 21

The average LTD ratio is 1.34 percent with a dispersion of 73.17 percent. The bank with lowest LTD rate is Standard Chartered Bank (2014/2015): 48.92percent and bank with highest LTD ratio is Sunrise bank (2016/2017): 87.28 percent and standard deviation is 9.33 percent is high. The average CAR rate is 12.52 percent. The minimum and maximum CAR rate are 10.84 percent (HBL-2015/16) and 21.08 percent (SCB - 2016/17) respectively. The average GDP growth rate in the study period is 3.97 percent. The maximum GDP is 7.40 percent in the $2016 / 17$ and minimum GDP is 0.10 percent recorded in $2015 / 16$. The average inflation rate is 8.12 percent. The maximum inflation rate 9.90 percent is reported in 2015/16.The dispersion rate of inflation is 2.08 percent exist in the study period.

\subsection{Correlations Analysis}

The correlation matrix of variables in model is expressed in Table 3, which shows that the absolute correlation value between pair of variables is all very low (below 0.5 ). However, to ensure that there is no multicollinearity between variables in the model, Wooldridge (2002) had suggested testing the Variance Inflation Factor (VIF) to check the multicollinearity problem. If the VIF is higher than 10 , there is the multicollinearity. Table 4 reports the VIF of all variables in the model, which all well below 10, and there is no multicollinearity between independent variables in the model.

The Table 3 shows that there is negatively associated between bank size and nonperforming loan ratio which indicates that higher the bank size lowers the nonperforming loan. The ROA and CAR are also negatively associated with the nonperforming loan. It indicates that when ROA and CAR increases the nonperforming decreases. 
Table 3 Pearson Correlations of Sample Banks

\begin{tabular}{|c|c|c|c|c|c|c|c|}
\hline Varibles & NPL & LnTA & ROA & LTD & CAR & GDP & INF \\
\hline NPL & 1 & & & & & & \\
\hline LnTA & $-.445^{* *}$ & 1 & & & & & \\
\hline ROA & -.167 & -.078 & 1 & & & & \\
\hline LTD & $.305^{*}$ & .111 & $-.310^{*}$ & 1 & & & \\
\hline CAR & $-.503^{* *}$ & .262 & -.144 & -.193 & 1 & & \\
\hline GDP & .019 & .023 & -.008 & .034 & .278 & 1 & \\
\hline INF & $.299^{*}$ & $-.377^{* * *}$ & .178 & -.152 & $-.494^{* * *}$ & $-.664^{* *}$ & 1 \\
\hline \multicolumn{8}{|c|}{ **. Correlation is significant at the 0.01 level (2-tailed). } \\
\hline *. Correla & gnificant & the 0.05 lev & -tailed). & & & & \\
\hline
\end{tabular}

Source: Annual Reports of Sample Banks and Results are drawn from SPSS - 21.0

The result shows that there is positive relationship of loan to deposit ratio and revealed that higher the LTD ratio, higher the nonperforming loan ratio. The GDP is positively associated with NPLs, it indicates that there positive relation exit between GDP and NPLs. The results shows that there is positive relationship of INF with NPLs which implies that INF is moving in the lines of nonperforming loan ratio.

\subsection{Regression Analysis}

Table 4 shows the R-squared which indicates the proportion of variability in the dependent variable which is explained by the regression model. The result indicates that the estimated model explains $51.0 \%$ of the variation in the non-performing loans ratio. Moreover, when R-squared is adjusted for positive bias $44.2 \%$ of the variation in the non-performing loans ratio is due to the explanatory variables.

Size (LnTA) has negative and statistically significant with NPLs. The result indicated that the inverse relation between size and NPLs. The priori hypothesis is rejected. The results consistent with study of Salas and Saurina (2002) had acknowledged the adverse relationship between the size of a bank and its NPL ratio. Rajan and Dhal (2003), Louzis et al. (2012) had reached the same conclusion with banks in India and Greece.

The ROA has negative and significant with nonperforming loan. The Priori hypothesis is accepted. It shows that the profitability increases NPL decrease and vice versa. The significant negative impact of the ROA on non-performing loans substantiates the view that risk taking is reduced in banks exhibiting high levels of performance. The result is also supportive of the bad management hypothesis and accords with the findings of Boudriga et al. (2010) and Beaton et al. (2016). However, the result is contrary to the significant positive effect of ROA on non-performing loans found by Swamy (2012) and Ahmad and Bashir (2013a).

Total loan and advance to total deposit have positive and significant with nonperforming loan. The result implies 
that when LTD is increases NPLs also increases. The Priori hypothesis is accepted. The empirical results indicate that the LTD has a significant positive effect on non performing loans. This finding suggests that with the growth in deposits banks engage in extensive lending, which leads to an increase in bank lending relative to deposits. Such aggressive lending behaviour results is in banks allocating funds to low quality borrowers, thereby increasing the riskiness of the loan portfolio and the level of non-performing loans. The result is supports the previous findings of Swamy (2012) and Ahmad and Bashir (2013a).

Capital adequacy ratio has negatively correlated with NPL ratio (-0.209) and statically significant $(0.011)$.Thus, priori hypothesis is accepted. The finding is contrary of Boudriga at al. (2010) and Rahaman et al. (2014), but supportive to Swamy (2012) and Shingjerji et al. (2013a) who found CAR to be negative and insignificant in their studies.

NPLs ratio and GDP growth showing positive relationship .The beta coefficient is (0.135) and is statistically significant $(0.049)$ at $5 \%$ level of significance, Hence the priori hypothesis is rejected. The findings is inconsistent with the studies of Salas and Saurina (2002); Louzis et al. (2012); Messai and Jouini (2013); Nkusu (2011); Makri et al. (2014); Klein (2013); Beck et al. (2013); and Tanasković and Jandrić (2015). When the economy experiences high GDP growth, the earnings of enterprises and citizen rise, in turn, it enhances the ability to repay the debt and reduce to NPL ratios. On the other hand, when the economy experiences low or negative GDP growth, the NPL ratio will increase.

The INF has positive but insignificant with NPLs. The priori hypothesis is accepted. The result of studies is consistent with the studies of Khemraj and Pasha (2009) and Fofack (2005). The findings is inconsistent of the studies of Farhan et al. (2012), Skarica (2013),Klein(2013), and Tomak (2013). When the economy suffers high inflation, the government usually implements tightening fiscal and monetary policies to restrict the credit growth to stabilize the macro-economics. 
Table 4 Regression Result of Determinants of Non- Performing Loans of Commercial Banks in Nepal

\begin{tabular}{|c|c|c|c|c|c|c|}
\hline \multirow[t]{2}{*}{ Variables } & \multirow[t]{2}{*}{ Coefficient } & \multirow[t]{2}{*}{ Std. Error } & \multirow[t]{2}{*}{$\mathbf{t}$} & \multirow[t]{2}{*}{ Sign } & \multicolumn{2}{|c|}{ Collinearity Statistics } \\
\hline & & & & & Tolerance & VIF \\
\hline (Constant) & 8.666 & 4.140 & 2.093 & .042 & & \\
\hline LnTA & -.698 & .294 & -2.375 & .022 & .755 & 1.324 \\
\hline ROA & -.410 & .219 & -1.873 & .068 & .846 & 1.182 \\
\hline LTD & .028 & .014 & 1.955 & .057 & .778 & 1.286 \\
\hline CAR & -.209 & .079 & -2.665 & .011 & .651 & 1.537 \\
\hline GDP & .135 & .067 & 2.022 & .049 & .484 & 2.065 \\
\hline INF & .156 & .096 & 1.627 & .111 & .345 & 2.899 \\
\hline
\end{tabular}

No of Observations: 50, R Square:0.510, Adjusted R Square: 0.442, F value:7.465, Probability: 0.000, DW: 1.075

Source: Annual Reports of Sample Banks and Results are drawn from SPSS - 21

The study focused on commercial banks in Nepal. The banks almost lend all the sectors of the economy and government as well but rising defaults on these loans are a matter of concern of this sector. The study presents an opportunity for commercial banks working in Nepal to change their lending policy, according to changes in bank specific and macroeconomic determinants which has an impact on rising default rates. The main purpose of the study is to determine the bank specific and macroeconomics determinants of nonperforming loans (NPLs) of commercial banks in Nepal. The study is based on secondary source of data of ten commercial banks. Convincing sampling method has been used in this study. The study has explained only six independent variables to analyze the effect of bank's specific and macroeconomic determinants on non performing loans with reference to Nepal from 2012/13 to 2016/17 leading to the total observations of fifty. Thus, the study concluded that bank specific: ROA, LTD and CAR and macroeconomic factors GDP have significant impact on nonperforming loan.

For future studies, researcher may also consider long time horizon and more variables like level of loan disbursed, collaterals value, and terms of credit, credit culture of society and bank ownership structure. Similarly, the methodological approach combining quantitative and qualitative approaches could be utilized in future 
studies on non-performing loans. The studies could be undertaken at a disaggregated level by decomposing loans by specific purpose (commercial, residential, and real estate mortgages), and by examining the interactions and relationships between non-performing loans and different types of borrowers, namely: individuals/households, small and medium-sized enterprises, and corporate borrowers. The research is based on a single country. Future empirical work on the determinants of non-performing loans can be conducted on other developing or developed countries.

The study suggests that the bank managers can control the NPL by boosting the profitability (ROA), diversifying the investment portfolios instead of lending, setting a reasonable credit growth, and restructuring the LTD. In addition, bank must stress on the risk management and strictly conform to credit rules and procedures. The government needs to have reasonable policies to maintain the stable economy growth, attract more investments by favorable mechanism, promote the growth of businesses, and improve the laws and financial system in accordance with international standards.

\section{References}

Abdullah, H., Ahmad, I., \& Bujang, I. (2015). Loan loss provisions and macroeconomic factors: The case of Malaysian commercialbanks. International Business Management, 9(4), 377-383. DOI: $10.3923 / \mathrm{ibm} .2015 .377 .383$

Aburime, U. T. (2009). Impact of political affiliation on bank profitability in Nigeria. African Journal of Accounting, Economics, Finance, and Banking Research, 4(4), 61-75.

Adebola, S., Yusoff, S. , and Dahalan, D., (2011). An ardl approach to the determinants of nonperforming loans. Kuwait Chapter of Arabian Journal of Business and Management Review, 1(.2), 36-51

Adhikary, D. K., Pant, R., \& Dhungana, B. R. (2007). Study on financial sector reform in Nepal. Prepared for South Asian Network of Economic institutes (SANEI). Institute of Development Economics. Quaid-i-Azam University, Islamabad, Pakistan.

Ahmad, F. \& Bashir, T. (2013a). Explanatory power of bank specific variables as determinants of non-performing loans: Evidence from Pakistan banking sector. World Applied Sciences Journal, 22(9), 1220-1231.

Amuakwa-Mensah, F.\& Boakye-Adjei, A. (2015). Determinants of non-performing loans in Ghana banking industry. Int. J. Computational Economics and Econometrics, 5(1), 35-54.

Anthony, W. \& Nakita, S. (2018). Determinants of non-performing loans: evidence from commercial banks in Barbados. The Business and Management Review, 9(3), 44-64. 7th International Conference on Business and Economic Development (ICBED), 9-10 April 2018, NY, USA.

Bajgain, B. (2016, June 2). Problematic \& liquidated financial institutions in Nepal. https://www.kantipurdaily.com/business/2016/06/02/20160602091826.html

Berge, T., \& Boye, K., (2007). An analysis of bank's problem loans. Norges Bank Economic Bulletin, 78, 65-76.

Bhattarai, S. (2015). Determinants of nonperforming loan in Nepalese commercial banks. Economic Journal of Development Issues, $19 \& 20(1-2)$ Combined Issue, 22-38 
Boudriga, A., Taktak, N. \& Jellouli, S. (2010). Bank specific, business and institutional environment determinants of banks nonperforming loans: Evidence from MENA countries. Economic Research Forum Working Paper No. 547.

Carey, M., (1998). Credit risk in private debt portfolios. Journal of Finance, 53, 1363-1387.

Demirguc-Kunt, A. \& Huizinga, H. (1999). Determinants of commercial bank interest margins and profitability: Some international evidence. The World Bank Economic Review, 13(2), 379-408.

Djiogap, F.\& Ngomsi, A.(2012): Determinants of bank long-term lending behavior in the Central African Economic and Monetary Community (CEMAC. Review of Economics \&Finance; 1923-7529-2012-02-107-08,

Ekanayake, E.M.N.N \& Azeez, A.A. (2015). Determinants of non-performing loans in licensed commercial banks: evidence from Sri Lanka. Asian Economic and Financial Review, 5(6):868-882. Retrieve from http://www.aessweb.om/journals/5002

Farhan, M., Sattar, A., Chaudhry, A., \& Khalil, F., (2012). Economic determinants of non-performing loans: Perception of Pakistani bankers. European Journal of Business and Management, 4(19), 44-61.

Fofack, H., (2005). Non-performing Loans in Sub-Saharan Africa: Causal analysis and macroeconomic implications. World Bank Policy Research Working Paper No. 3769.

Ghosh, A. (2015). Banking-industry specific and regional economic determinants of nonperforming loans: Evidence from US states. Journal of Financial Stability, 20, 93-104.

Guy, K. \& Lowe, S. (2011). Non-performing loans and bank stability in Barbados. Central Bank of Barbados Economic Review, XXXVII (3), 77-99.

Jin-Li, H.Yang, L. \& Yung-Ho, C. (2006). Ownership and non-performing loans: Evidence from Taiwan's banks. Developing Economies, (Forthcoming). Institutional, Environment Determinants of Nonperforming Loans: Evidence from MENA Countries, Journal of Financial Economic Policy, 1(4), 286-318

Jimenez, G., Salas V. \& Saurina J. (2006). Determinants of collateral. Journal of Financial Economics, 81(2), 255-281.

Khaled, S.R. (2016). Determinants of non-performing loans: Evidence from the Jordanian banking sector. Journal of Finance and Bank Management June 2016, 4(1), 125-136. URL: https://doi.org/10.15640/jfbm.v4n1a9

Khan, I. \& Ahmad, A. (2017). Assessing banks internal factors as determinants of non-performing loans: Evidence from Pakistani commercial banks. Journal of Managerial Sciences, XI(1),109- 125.

Khemraj, T., \& Pasha, S., (2009). The determinants of non-performing loans: an econometric case study of Guyana. Presented at the Caribbean Centre for Banking and Finance Bi-annual Conference on Banking and Finance, St. Augustine, Trinidad.

Jameel , K. (2014). Crucial factors of nonperforming loans evidence from Pakistani banking sector. International Journal of Scientific \& Engineering Research, 5( 7), $704-710$.

Louzis, D. P., Vouldis, A. T. \& Metaxas, V. L. (2012). Macroeconomic and bank-specific determinants of non-performing loans in Greece: A comparative study of mortgage, business and consumer loan portfolios. Journal of Banking \& Finance,36(10), 45-61.

Makri, V., Tsagkanos , A. \& Bellas, A. (2014). Determinants of non-performing loans: The case of Eurozone. Panoeconomicus, 61(2), 193-206.

Messai A. S. and Jouini F. (2013). "Micro and macro determinants of non-performing loans", International Journal of Economics and Financial Issues, Vol. 3, No. 4, pp. 852-860. 
Nguyen, T. M. H. (2015). Non-performing loans: Affecting factor for the sustainability of Vietnam commercial banks - An econometric study. Vietnam's Socio-Economic Development — A Social Science Review, 77, $32-45$.

Nkusu M. (2011). Nonperforming loans and macrofinancial vulnerabilities in advanced economies. IMF Working Papers, 1-27.

Nkusu, M., (2011). Nonperforming loans and macro financial vulnerabilities in advanced economies. IMF Working Paper 11/161 (Washington: International Monetary Fund).

NRB. (2017/18). Monetary Policy. Baluwatar, Kathmandu: Nepal Rastra Bank.

Ozurumba, B. A. (2016). Impact of non-performing loans on the performance of selected commercial banks in Nigeria. Research Journal of Finance and Accounting 7(16), 95-109. www.iiste.org. ISSN 2222-1697 (Paper) ISSN 2222-2847 (Online)

Prasanna, P.K., Thenmozhi, M., \& Rana, N. (2014). Determinants of non-performing advances in Indian banking system. Banks and Bank Systems, 9(2), 65-77.

Rajan, R. \& Dhal, S. C. (2003). Non-performing loans and terms of credit of public sector banks in India: An empirical assessment. Occasional Papers, 24(3), 81-121. Reserve Bank of India.

Roy, S. G. (2014). Determinants of non-performing assets in India - panel regression. Eurasian Journal of Economics and Finance, 2(3), 2014, 69-78 DOI: 10.15604/ejef.2014.02.03.005

Salas, V. \& Saurina, J. (2002). Credit risk in two institutional regimes: Spanish commercial and savings banks. Journal of Financial Services Research, 22(3), 203-224.

Salas, V., \& Saurina, J., (2006). Determinants of collateral. Journal of Financial Economics, 81, $255-281$.

Salas, V., \& Saurina. J,. (2002). Credit Risk in two institutional regimes: Spanish commercial and savings banks. Journal of Financial Services Research, 22(3) 203-224.

Sapkota, C. (2011). Nepalese banking crisis explained. Journal of Institute of chartered Accounts of Nepal, 13, 4

Sinkey, J. F. \& Mary B. G. (1991). Loan-loss experience and risk-taking behavior at large commercial banks. Journal of Financial Services Research, 5, 43-59.

Tanasković, S. \& Jandrić , M. (2015). Macroeconomic and institutional determinants of non-performing loans. Journal of Central Banking Theory and Practice, 4(1), 47-62.

Tseganesh, T. (2012). Determinants of banks liquidity and their impact on financial performance. Published Thesis (MSc), University Addis Ababa, Ethiopia

\section{Copyrights}

Copyright for this article is retained by the author(s), with first publication rights granted to the journal.

This is an open-access article distributed under the terms and conditions of the Creative Commons Attribution license (http://creativecommons.org/licenses/by/4.0/). 